\title{
Arsenic, lead and nickel accumulation in Rubus ulmifolius growing in contaminated soil in Portugal
}

\author{
Ana P.G.C. Marques, Helena Moreira, António O.S.S. Rangel, Paula M.L. Castro* \\ Escola Superior de Biotecnologia, Universidade Católica Portuguesa, Rua Dr. António Bernardino de Almeida, 4200-072 Porto, Portugal
}

\author{
Keywords: \\ Arsenic \\ Lead \\ Nickel \\ Phytoremediation \\ Rubus ulmifolius
}

\begin{abstract}
A B S T R A C T
This work investigates the potential of Rubus ulmifolius, indigenous to a metal contaminated site - Esteiro de Estarreja - for phytoremediation purposes. The site has a long history of metal contamination. The accumulation of lead ( $\mathrm{Pb}$ ), arsenic (As) and nickel (Ni) in different sections - roots, stems and leaves - of the plant was assessed and compared to the levels of those metals in the soil and in the available fraction. The distribution of metals throughout the area was quite heterogeneous, presenting levels of $\mathrm{As}$, Pb and $\mathrm{Ni}$ of up to 3078,1400 and $135 \mathrm{mg} \mathrm{kg}^{-1}$, respectively, and the metal content in the sections of R. ulmifolius collected in the banks of the stream varied among sites of collection. Levels of metals were higher in the plant roots: As levels ( $\mathrm{mg} \mathrm{kg}^{-1}$ ) ranged from 277 to 1721 in the roots, 30 to 110 in the stems, and 60 to 265 in the leaves; $\mathrm{Pb}$ concentrations $\left(\mathrm{mg} \mathrm{kg}^{-1}\right)$ ranged from 248 to 1178 in the roots, 35 to 133 in the stems, and 25 to 149 in the leaves; and $\mathrm{Ni}\left(\mathrm{mg} \mathrm{kg}^{-1}\right)$ ranged from 48 to 151 in the roots. Significant correlations were found between the total levels of $\mathrm{Pb}$ and $\mathrm{As}$ in the soil and the levels in the roots of the plant; further correlations between total and available levels in the soil and metals in other plant tissues were generally found as non-significant. According to the metal accumulation patterns of $R$. ulmifolius, this species seems to be valuable for application in phytostabilisation strategies.
\end{abstract}

\section{Capsule}

Arsenic, lead and nickel accumulation by R. ulmifolius growing in contaminated soils was high in the plant roots, indicating a tolerance strategy which renders the plant with potential for application in phytostabilisation strategies.

\section{Introduction}

Heavy metals are contaminants of much environmental concern, as they are hazardous to humans and other biota. Depending on their physical-chemical state and the prevailing chemical conditions, metal contamination can cause soil and groundwater pollution, soil structure deterioration, destruction of the ecological landscape and decrease in biological diversity [1,2]-with disappearance of the vegetation cover and consequent aggravated risk posed by a baren metal contaminated soil to the surrounding area and its inhabitants. The application of traditional methods of remediation to metal contaminated soils can become very costly and

\footnotetext{
* Corresponding author. Tel.: +351 2255800 59; fax: +351225090351.
} E-mail addresses: amarques@mail.esb.ucp.pt (A.P.G.C. Marques), helenamoreira@hotmail.com (H. Moreira), aorangel@esb.ucp.pt (A.O.S.S. Rangel), plcastro@esb.ucp.pt (P.M.L. Castro). may only affect the upper layers of the soil [3]. The use of plants to remove or immobilise the contaminants - phytoremediation offers a low cost method for soil remediation.

A number of plant species endemic to metalliferous soils were found to be able to accumulate metals to levels exceeding those considered as phytotoxic [4]. Proper selection of plant species for phytoremediation plays an important role in the development of remediation methods [5]. Specific constraints related to the soil, climate, context of application, among others are important factors to consider in the application of a specific plant species to a soil. Heavy metals can cause severe toxicity and may act as a powerful force for the evolution of tolerant plant populations. The search for indigenous plants, often better in terms of survival, growth and reproduction under metal-stressful field conditions may be an adequate approach to find plant species with metal resistance capabilities and even with the capacity to accumulate metals at very high levels [6,7]. Although there has been a continuing interest in this area, few studies have contributed to the evaluation of the phytoremediation potential of native plants under field conditions. Different phytotechnologies make use of different plant properties [8]. In phytostabilisation, plants are used to stabilise the soil surface, by retaining the metals in the roots, reducing mobility and bioavailability of environmental pollutants and consequently decreasing erosion and leaching of metals to the soil deeper layers [9]. Metal-tolerant plant species are applied to immobilise heavy 
metals belowground, decreasing metal mobility and reducing the likelihood of metals entering into the food chain [10]. Phytoextraction is based on the capacity of the roots of plants to absorb and translocate toxic metals from soil to the aboveground harvestable plant tissues (harvestable regions) [11]-the concentration process results in a reduction of the contaminated mass and also in the transfer of the metal from an aluminosilicate-based matrix (soil) to a carbon-based matrix (plants) [12].

This work investigates the potential of a species indigenous to a metal contaminated site for phytoremediation purposes. The site has a long history of metal contamination, due to the industrial activity in the surrounding area [13]. For many years the discharge of solid residues directly into the ground and of the industrial wastewaters into a stream - "Esteiro de Estarreja" - induced a contamination scenario in which the levels of heavy metals in the sediments of this stream are above the limits established by EC Directive 86/278/EC. Among the metals present at higher levels in those sediments, $\mathrm{Pb}, \mathrm{As}$, and $\mathrm{Ni}$ appear as the contaminants with the higher hazard degree. It is known from previous studies that the contamination along the banks of the stream is very heterogeneous, with the area near the former exit of contaminated wastewaters being the most polluted and occurring mainly in the top $20 \mathrm{~cm}$ layer of the soil $[13,14,15]$. Despite this pollution situation, the vegetation remains abundant, and throughout the years a species has been taking over the site-Rubus ulmifolius Schott. Studies evaluating metal accumulation by $R$. ulmifolius are yet not common.

The aim of this study was to determine the accumulation of heavy metals, namely $\mathrm{Pb}, \mathrm{As}$ and $\mathrm{Ni}$, in different sections - roots, stems, and leaves - of $R$. ulmifolius colonizing a contaminated site and to relate that feature to the metal content of the soil. According to the accumulation patterns and abilities of R. ulmifolius, the analysis of its possible application in soil phytoremediation - either phytoextraction or phytoestabilisation - was evaluated.

\section{Materials and methods}

\section{Research site and sampling techniques}

Plant and soil sampling was made at four different spots in the bank where this species was predominant (the right bank of the stream) starting near the conduct exit and following the stream course. The collection spots were separated by $20 \mathrm{~m}$ from each other, in order to cover a diverse range of soil metal concentrations, potentially toxic to plants, profiting from the heterogeneity of the site contamination (Fig. 1). At each sampling location, $0.5 \mathrm{~m}$ sided squares delimited the spot from which plant samples were collected. In each square three plants were collected randomly-selected plants were ca. $1 \mathrm{~m}$ in height and presented no visual toxicity signs. A soil sample from each plant rooting zone $(0-20 \mathrm{~cm}$ depth) was also collected. Sampling was made in the dry and flowering season (April).

\subsection{Soil analysis}

The following methods were based on Houba et al. [16]. Soil samples - three replicates for each sampling location - were

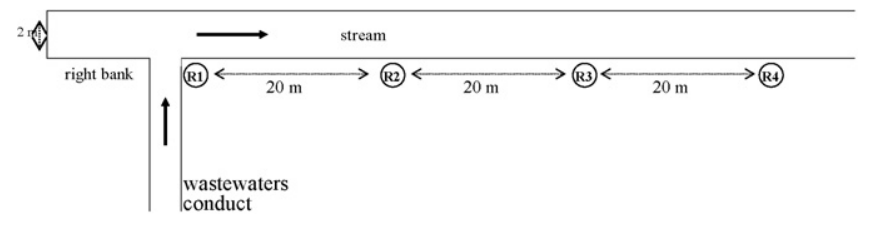

Fig. 1. Scheme of the study area. oven dried at $40^{\circ} \mathrm{C}$ for $48 \mathrm{~h}$ and passed through a $2 \mathrm{~mm}$ sieve. The soil $\mathrm{pH}$ was measured using a 1:2.5 soil water ratio. Water content was determined by drying pre-oven dried $\left(40^{\circ} \mathrm{C}\right)$ soil at $105^{\circ} \mathrm{C}$ until constant mass was achieved. Organic matter content was determined by loss on ignition. Samples for total phosphorous and nitrogen were digested at high temperatures (up to $330^{\circ} \mathrm{C}$ ) with a selenium and salicylic and sulphuric acids mixture. For total nitrogen colorimetric determination, two reagents were added to the digests: reagent 1 , consisting of a mixture of a $5 \times 10^{-2} \mathrm{M}$ disodiumhydrogenphosphate buffer $(\mathrm{pH} 12.3)$ and a $4 \%$ bleach solution and reagent 2 consisting of a mixture of a $1 \mathrm{M}$ sodium salicylate solution, a $1 \times 10^{-3} \mathrm{M}$ sodium nitroprusside solution and a $3 \times 10^{-3} \mathrm{M}$ EDTA solution. For total phosphorous colorimetric determination, two different reagents were added to the digests: reagent 1 , consisting of a $3 \times 10^{-2} \mathrm{M}$ ascorbic acid solution and reagent 2 consisting of a mixture of a $6 \times 10^{-3} \mathrm{M}$ antimonyl tartarate solution, a $5 \times 10^{-3} \mathrm{M}$ ammonium molybdate solution, $0.7 \mathrm{M}$ sulphuric acid and an anticoagulation agent (Wetting aerosol 22, Cytek, New Jersey, USA). The elements concentration on the resulting preparations was determined on an UNICAM HELIOS $^{\circledR}$ spectrophotometer (Waltham, USA), at $660 \mathrm{~nm}$ for nitrogen and $880 \mathrm{~nm}$ for phosphorous. For total soil metals determination, soil samples were digested at high temperatures (up to $140^{\circ} \mathrm{C}$ ) with concentrated nitric and hydrochloric acids $(1: 1)$. The available [17]-ethilenediaminetetraacetic acid (EDTA) extractable metal fractions were determined using a 1:10 soil $0.05 \mathrm{M}$ EDTA ratio. The resulting solutions were incubated for $2 \mathrm{~h}$ at $20^{\circ} \mathrm{C}$, after which they were filtrated through a $0.45 \mu \mathrm{m}$ cellulose acetate filter. The metal $(\mathrm{Pb}, \mathrm{As}, \mathrm{Ni})$ content of the resulting digests and extracts were determined using inductively coupled plasma mass spectroscopy (ICP-MS) in a Varian $730-$ ES $^{\circledR}$ spectrophotometer (Palo Alto, USA).

\section{Plant analysis}

Entire plants - three replicates for each sampling location - were washed with tap water, followed by washing with $\mathrm{HCl}$ $0.1 \mathrm{M}$, and with de-mineralised water, after which they were separated in roots, stems, and leaves, oven dried at $70^{\circ} \mathrm{C}$ for $48 \mathrm{~h}$, grinded, and sieved to $<1 \mathrm{~mm}$. The resulting samples were digested at high temperature (up to $205^{\circ} \mathrm{C}$ ) with a mixture of concentrated nitric, perchloric and sulphuric acids (40:4:1). Metal $(\mathrm{Pb}, \mathrm{As}, \mathrm{Ni})$ content was determined using ICP-MS of the digests [18].

\section{Statistical analysis}

Statistical analysis was performed using the SPSS program (SPSS Inc., Chicago, IL, Version 12.0). Three independent replicates were used for each treatment group. The variance homogeneity and the normality of the distribution were verified in each group. The data concerning As and $\mathrm{Pb}$ levels of accumulation versus plant tissue and versus sampling location were analysed through analysis of variance (two-way ANOVA). As, $\mathrm{Pb}$ and $\mathrm{Ni}$ levels versus plant tissue was analysed through one-way ANOVA and the Tukey test was performed to detect the statistical significance of differences $(P<0.05)$ between means in this analysis. Correlations were performed with different variables and Spearman's correlation coefficients were determined.

\section{Chemicals}

The chemicals used were analytical-grade and were obtained from Pronalab (liquid reagents) and Merck (solid reagents). 
Table 1

Soil properties of the study site.

\begin{tabular}{|c|c|c|c|c|c|}
\hline Collection site & $\mathrm{pH}$ & Water content (\%) & Organic content (\%) & $\mathrm{N}\left(\mathrm{mg} \mathrm{kg}^{-1}\right)$ & $\mathrm{P}\left(\mathrm{mg} \mathrm{kg}^{-1}\right)$ \\
\hline R1 & $7.13 \pm 0.4$ & $1.46 \pm 0.09$ & $10.1 \pm 0.2$ & $3513 \pm 4$ & $201 \pm 8$ \\
\hline $\mathrm{R} 2$ & $6.49 \pm 0.1$ & $1.4 \pm 0.1$ & $8.4 \pm 0.3$ & $1596 \pm 10$ & $282 \pm 4$ \\
\hline R3 & $6.33 \pm 0.2$ & $1.6 \pm 0.1$ & $7.9 \pm 0.3$ & $3359 \pm 5$ & $255 \pm 8$ \\
\hline R4 & $7.14 \pm 0.1$ & $1.60 \pm 0.09$ & $9.5 \pm 0.2$ & $1118 \pm 13$ & $44 \pm 4$ \\
\hline
\end{tabular}

Results are expressed as mean \pm S.D.

Table 2

Total and extractable metal concentrations in soils from different sampling locations.

\begin{tabular}{|c|c|c|c|c|c|c|}
\hline \multirow[t]{3}{*}{ Collection site } & \multicolumn{6}{|l|}{ Metal } \\
\hline & \multicolumn{2}{|l|}{ As } & \multicolumn{2}{|l|}{$\mathrm{Pb}$} & \multicolumn{2}{|l|}{$\mathrm{Ni}$} \\
\hline & Total & EDTA extract & Total & EDTA extract & Total & EDTA extract \\
\hline $\mathrm{R} 1$ & $3078 \pm 117 a$ & $43 \pm 2 a$ & $1400 \pm 9 a$ & $204 \pm 5 a$ & $96 \pm 5 b$ & $2.23 \pm 0.05 b$ \\
\hline $\mathrm{R} 2$ & $952 \pm 13 b$ & $26 \pm 3 b$ & $371 \pm 1 c$ & $67 \pm 10 \mathrm{~b}$ & $135 \pm 10 a$ & $9 \pm 1 a$ \\
\hline R3 & $1180 \pm 24 b$ & $8.7 \pm 02 c$ & $611 \pm 7 b$ & $77 \pm 3 b$ & $63 \pm 2 c$ & $2.01 \pm 0.05 b$ \\
\hline \multirow[t]{2}{*}{ R4 } & $1126 \pm 27 \mathrm{~b}$ & $20 \pm 3 \mathrm{~b}$ & $540 \pm 9 b$ & $83 \pm 9 b$ & $105 \pm 3 b$ & $3.7 \pm 0.4 \mathrm{~b}$ \\
\hline & ${ }^{* * *}(F=264)$ & ${ }^{* * *}(F=32)$ & ${ }^{* * *}(F=214)$ & ${ }^{* * *}(F=81)$ & ${ }^{* * * *}(F=28)$ & ${ }^{* * *}(F=38)$ \\
\hline
\end{tabular}

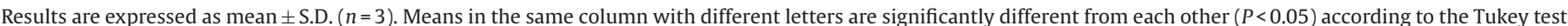

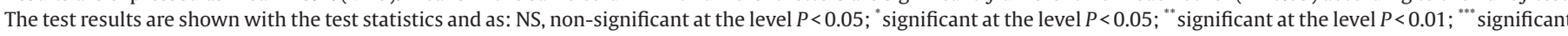
at the level $P<0.001$.

\section{Results}

Soils

The soil collected from the banks of the stream presented a range of $\mathrm{pH}$ from 6.33 to 7.14 , a water content ranging from $1.4 \%$ to $1.6 \%$, and organic matter contents ranging from $7.9 \%$ to $10.1 \%$. The nutrient content of the soils was variable, with $\mathrm{N}$ ranging from 44 to $282 \mathrm{mg} \mathrm{kg}^{-1}$ and P levels ranging from 44 to $282 \mathrm{mg} \mathrm{kg}^{-1}$ (Table 1 ).

The total metal concentration in the soil was variable along the stream, with some significant $(P<0.05)$ differences registered within the sampling points (Table 2 ). The highest levels of As and $\mathrm{Pb}$ were registered in the first sampling point, located near the former exit of contaminated wastewaters, and were of 3078 and $1400 \mathrm{mg} \mathrm{kg}^{-1}$, respectively; the highest $\mathrm{Ni}$ level in the soil was $135 \mathrm{mg} \mathrm{kg}^{-1}$ (values shown are in dry weight).

Spearman's correlation analyses of the levels of metals in the soils versus the available (EDTA extractable) fractions were performed - strong significant and positive correlations were found between total concentration in the soil and the metal levels in the available fractions - ranging from 0.77 to 0.96 (Table 3 ). Thus, EDTA soil extractable fractions were also different from point to point: lower in collection sites R3 for As and Ni and R2 for Pb and higher in the same locations as for the total levels-in collection site R1 for As and $\mathrm{Pb}$ and in collection site R2 for Ni (Table 2).

\section{Plants}

The metal content in the sections of $R$. ulmifolius collected in the banks of the stream varied among sites of collection (Fig. 2). Arsenic

Table 3

Spearman's correlation coefficients between total metal concentration in the soil and available levels.

\begin{tabular}{llll}
\hline & Soil factors & & \\
\cline { 2 - 4 } & EDTA extractable, As & EDTA extractable, Pb & EDTA extractable, Ni \\
\hline Total As & $0.77^{* *}$ & n.a. & n.a. \\
Total Pb & n.a. & $0.96^{* *}$ & n.a. \\
Total Ni & n.a. & n.a. & $0.85^{* *}$ \\
\hline
\end{tabular}

n.a., not applicable.

** Correlation is significant at the 0.01 level. levels ( $\mathrm{mg} \mathrm{kg}^{-1}$ ) ranged from 277 to 1721 in the roots, 30 to 110 in the stems, and 60 to 265 in the leaves; $\mathrm{Pb}$ concentrations $\left(\mathrm{mg} \mathrm{kg}^{-1}\right)$ ranged from 248 to 1178 in the roots, 35 to 133 in the stems, and 25 to 149 in the leaves; and $\mathrm{Ni}\left(\mathrm{mg} \mathrm{kg}^{-1}\right)$ ranged from 48 to 151 in the roots, whereas Ni was not detected (Detection limit $=0.1 \mathrm{mg} \mathrm{L}^{-1}$ ) in the remaining sections (values shown are in dry weight).

Significant $(P<0.05)$ differences between the As levels in the roots, stems and leaves were observed, with the roots presenting the highest accumulation levels, followed by the leaves and then the stems. Significant $(P<0.05)$ differences were registered between the levels of $\mathrm{Pb}$ in the roots and the aboveground sections, but not between leaves and stems.

\section{Soil - plant relaction}

Spearman's correlation analyses were performed with the levels of metals in plants roots, stems and leaves versus the available metal concentrations in the soil (Table 4). Positive correlations were found between total $\mathrm{Pb}$ and As concentrations in the soil and the metal levels in the roots of the plant. As to the remaining values, the correlations were generally not significant.

Spearman's correlation analyses were made also between $\mathrm{pH}$ loss on ignition $\mathrm{C}, \mathrm{N}$ and $\mathrm{P}$ values, but few significant correlations were found, with special emphasis for the correlations found between the $\mathrm{N}$ levels in the soils and the $\mathrm{As}, \mathrm{Pb}$ and $\mathrm{Ni}$ accumulation in the roots (Table 4).

Bioconcentration factors (BCFs) were determined for the different plant sections (root, stems and leaves), expressed as the ratio between the metal concentration in the plant section and in soil (Fig. 3). The highest BCF values were registered for the roots of $R$. ulmifolius, and in some of these cases values higher than 1 were observed. For the plant stems and leaves, low BCF values (generally lower than 0.2) were observed.

\section{Discussion}

The total metal concentrations in the soil were variable along the stream, corroborating the data obtained by Atkins [14]. A range of soil metal concentrations was thus covered in this study. The levels are much higher than those proposed by some authors as normal in soils: $2-100 \mathrm{mg} \mathrm{Ni} \mathrm{kg}^{-1}$ [19], 2-300 $\mathrm{mg} \mathrm{Pb} \mathrm{kg}^{-1}$ [20] and 
Table 4

Spearman's correlation coefficients between metal concentration in the plant parts and soil factors.

\begin{tabular}{|c|c|c|c|c|c|c|c|}
\hline & & \multicolumn{6}{|c|}{ Plant-soil factors } \\
\hline & & Total & EDTA extractable & $\mathrm{pH}$ & $\mathrm{N}$ & $\mathrm{P}$ & $\mathrm{C}$ \\
\hline Roots & $\begin{array}{l}\text { As }(n=3) \\
\mathrm{Pb}(n=3) \\
\mathrm{Ni}(n=3)\end{array}$ & $\begin{array}{l}0.706^{*} \\
0.608^{*} \\
\text { n.s. }\end{array}$ & $\begin{array}{l}\text { n.s. } \\
\text { n.s. } \\
\text { n.s. }\end{array}$ & $\begin{array}{l}\text { n.s. } \\
\text { n.s. } \\
\text { n.s. }\end{array}$ & $\begin{array}{l}0.937^{* *} \\
0.748^{* *} \\
0.670^{* *}\end{array}$ & $\begin{array}{l}\text { n.s. } \\
\text { n.s. } \\
-0.862^{* *}\end{array}$ & $\begin{array}{l}\text { n.s. } \\
\text { n.s. } \\
\text { n.s. }\end{array}$ \\
\hline Stems & $\begin{array}{l}\text { As }(n=3) \\
\mathrm{Pb}(n=3) \\
\mathrm{Ni}(n=3)\end{array}$ & $\begin{array}{l}\text { n.s. } \\
0.818^{* *} \\
\text { n.a. }\end{array}$ & $\begin{array}{l}\text { n.s. } \\
\text { n.s. } \\
\text { n.a. }\end{array}$ & $\begin{array}{l}\text { n.s. } \\
\text { n.s. } \\
\text { n.a. }\end{array}$ & $\begin{array}{l}\text { n.s. } \\
0.769^{* *} \\
\text { n.a. }\end{array}$ & $\begin{array}{l}\text { n.s. } \\
\text { n.s. } \\
\text { n.a. }\end{array}$ & $\begin{array}{l}-0.764^{* *} \\
\text { n.s. } \\
\text { n.a. }\end{array}$ \\
\hline Leaves & $\begin{array}{l}\text { As }(n=3) \\
\mathrm{Pb}(n=3) \\
\mathrm{Ni}(n=3)\end{array}$ & $\begin{array}{l}\text { n.s. } \\
\text { n.s. } \\
\text { n.a. }\end{array}$ & $\begin{array}{l}\text { n.s. } \\
\text { n.s. } \\
\text { n.a. }\end{array}$ & $\begin{array}{l}\text { n.s. } \\
\text { n.s. } \\
\text { n.a. }\end{array}$ & $\begin{array}{l}\text { n.s. } \\
\text { n.s. } \\
\text { n.a. }\end{array}$ & $\begin{array}{l}\text { n.s. } \\
\text { n.s. } \\
\text { n.a. }\end{array}$ & $\begin{array}{l}\text { n.s. } \\
\text { n.s. } \\
\text { n.a. }\end{array}$ \\
\hline
\end{tabular}

n.s., no significant correlation; n.a., non-applicable as Ni was not detected in the stems and leaves of the plants.

* Correlation is significant at the 0.05 level.

** Correlation is significant at the 0.01 level.

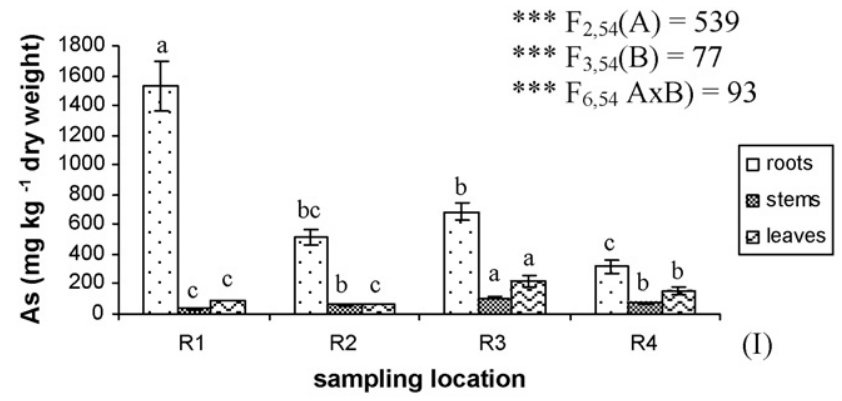

(I)
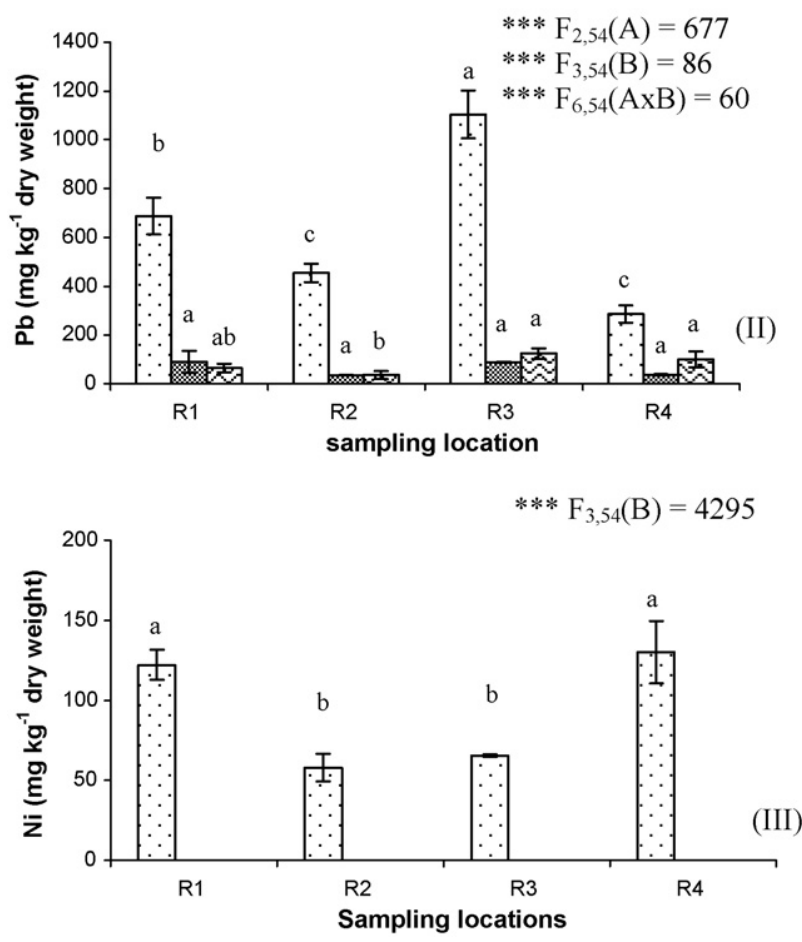

Fig. 2. As (I), $\mathrm{Pb}(\mathrm{II})$ and $\mathrm{Ni}$ (III) levels in R. ulmifolius sections. Results are expressed as means \pm S.D. $(n=3)$. One-way ANOVA was performed for each plant section. Means for the same plant section with different letters are significantly different from each other $(P<0.05)$ according to the Tukey test. Two-way ANOVA was performed to determine the influence of plant section and of sampling location in plant As and $\mathrm{Pb}$ concentration (for Ni results of one-way ANOVA are presented). The test results are shown with the test statistic for each case (A: plant section; B: sampling location; $A \times B$ : plant section $\times$ sampling location) and as: NS, non-significant at the level $P<0.05$; ${ }^{*}$ significant at the level $P<0.05 ;{ }^{* *}$ significant at the level $P<0.01$; ${ }_{* * * *}$ significant at the level $P<0.001$.
$0.1-40 \mathrm{mg} \mathrm{As} \mathrm{kg}^{-1}$ [21]. Heavy metal toxicity depends not only on their total concentration but also on the bioavailability (defined as the ease with which they pass into the soil solution and thereby into the trophic chain) [22]. The metals considered readily available for plant uptake represent often only a small portion of the total metal content of the soil [12], as was found in this study, with the levels of EDTA extractable $\mathrm{Pb}$, As and Ni representing 13\%, $0.7 \%$ and $2.4 \%$ of the total metal contents present in the soils, respectively. The analysis of the potential bioavailable metal fraction is considered probably more significant than the analysis of total contents [22], because the former allows prediction of the risk of metal uptake by plants and its mobility within the ecosystem. Nevertheless, this relation was not observed in this study, as generally no
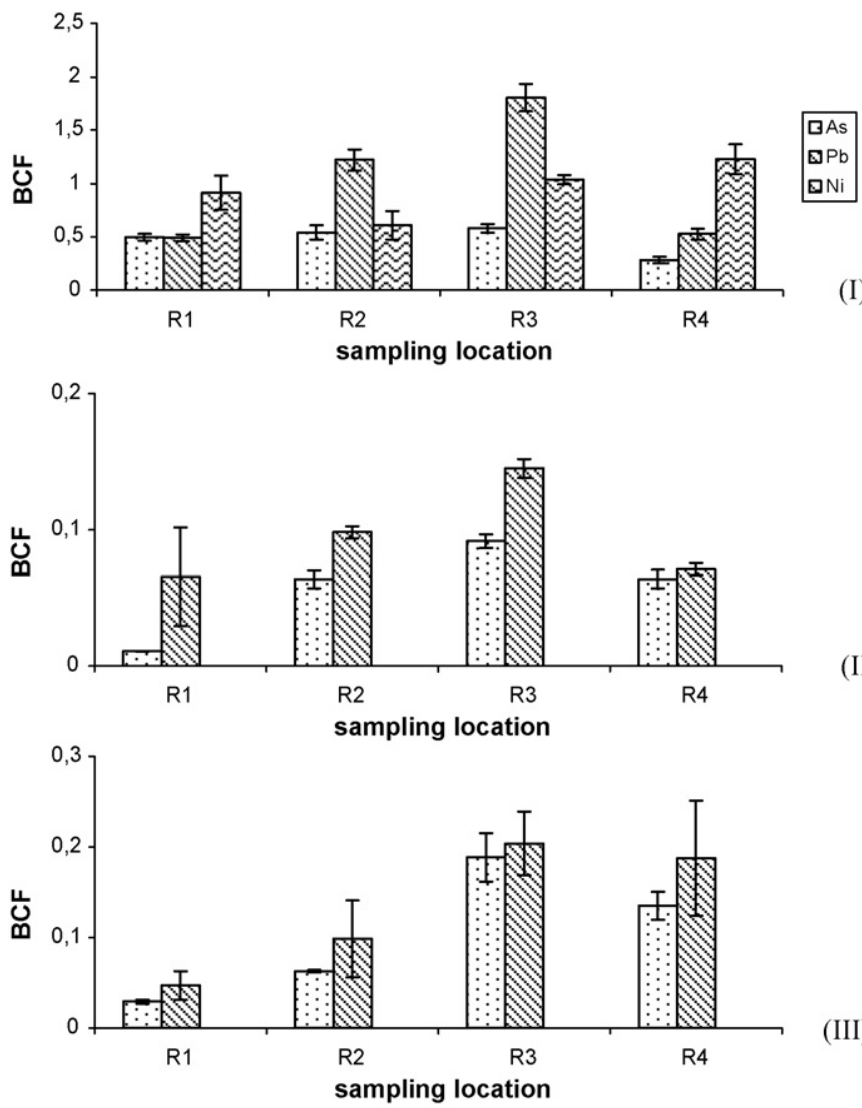

Fig. 3. Bioconcentration factors (BCF) for R. ulmifolius roots (I), stems (II) and leaves (III). Results are expressed as means \pm S.D. $(n=3)$. 
correlations between EDTA extractable concentrations and the levels in the plants were found. Similar patterns have been shown in previous studies in which the accumulation of metals, such as $\mathrm{Ni}$, did not correlate with the soil metal concentration $[23,24]$. In fact, when correlating the levels of total and available (EDTA extractable) metals in the soil with the levels occurring in the plants, correlations were only found for the roots of the plant and for total levels of $\mathrm{As}$ and $\mathrm{Pb}$ in the soil. According to the reports found in the literature, a relatively clear pattern of increasing plant accumulation with increasing soil concentration is usually found only for $\mathrm{Zn}[13,25]$. However, the lack of correlation obtained in the majority of cases may imply that in isolation the level of available metal is not dominant in determining metal accumulation by that plant part. It is possible that variation of metal availability and accumulation with parameters such as organic content [26], pH [27], and soil nutrient status [28] obscures any possible relationship between the total concentrations in the soil, the available levels and levels in the plant. In this study, Spearman's correlation analyses were performed to determine the effect of these soil factors in metal accumulation by R. ulmifolius, but generally no relationships were found. Previous reports have shown pH-dependent accumulation of metals by plants $[27,28]$, but this was not observed in this study. The apparent lack of influence of $\mathrm{P}$ and $\mathrm{C}$ has been also reported for $\mathrm{Pb}, \mathrm{Zn}$ and $\mathrm{Cd}$ accumulation in Equisteum ramosisti [28]. A correlation with $\mathrm{N}$ levels in the soil was found for metal accumulation in the roots; nonetheless, the absence of correlation for the stems and leaves can be explained by a possible "dilution effect" caused by improved aboveground biomass under N-rich soil conditions [19]. Spearman's correlation analyses presented in this study were performed only with metal concentration in plant tissues and the independent soil factors, reinforcing the hypothesis that in the field metal accumulation results from a dynamic interaction of factors, such as salinity [29], oxygen and proton release [30] and it is not possible to isolate the effect of each one.

The levels of accumulation obtained in this study are quite high when compared with data presented in literature for plants grown in non-impacted soil-0.1-5 mg Pb [31], 0.01-5 mg As [32] and 1-10 mg Ni [33], per kg of plant dry weight. Additionally, the observed levels of $\mathrm{As}, \mathrm{Pb}$ and $\mathrm{Ni}$, in $R$. ulmifolius growing in the field - maximum levels of $1721 \mathrm{mg} \mathrm{As} \mathrm{kg}^{-1}, 1178 \mathrm{mg} \mathrm{Pb} \mathrm{kg}^{-1}$ and $151 \mathrm{mg} \mathrm{Ni} \mathrm{kg}^{-1}$ in the roots and $265 \mathrm{mg} \mathrm{As} \mathrm{kg}^{-1}$ and $149 \mathrm{mg} \mathrm{Pb} \mathrm{kg}^{-1}$ in the leaves - were higher than other reported values for field collections. Stoltz and Greger [30] reported for Erioforum angustifolium, Phragmites australis and Salix sp. maximum accumulations of $38 \mathrm{mg} \mathrm{Pb} \mathrm{kg}^{-1}$ and $8.4 \mathrm{mg} \mathrm{As} \mathrm{kg}^{-1}$, and $920 \mathrm{mg} \mathrm{Pb} \mathrm{kg}^{-1}$ and $276 \mathrm{mg} \mathrm{As} \mathrm{kg}^{-1}$, in the aboveground and belowground tissues, respectively. Haque et al. [34] reported for Baccharis sarothroides levels of up to 152,45 and $97 \mathrm{mg} \mathrm{kg}^{-1}$ of $\mathrm{Pb}$, As and $\mathrm{Ni}$, respectively, in the roots, and 107,37 and $31 \mathrm{mg} \mathrm{kg}^{-1}$ of $\mathrm{Pb}, \mathrm{As}$ and $\mathrm{Ni}$, in that order, in the shoots. Yoon et al. [7] analysed another blackberry species, Rubus fruticosus, and have found levels of $\mathrm{Pb}$ of up to 825 and $22 \mathrm{mg} \mathrm{kg}^{-1}$ in the roots and shoots when grown in soil contaminated with $4100 \mathrm{mg} \mathrm{kg}^{-1}$-a lower accumulation for a much more contaminated soil than that observed presently for $R$. ulmifolius.

R. ulmifolius never accumulated more than $1000 \mathrm{mg} \mathrm{kg}^{-1}$ of any of the metals in the aboveground tissues, the criteria indicated for $\mathrm{As}, \mathrm{Pb}$ or Ni hyperaccumulators [12]. In fact, the metals were mainly accumulated in the roots of the plant, indicating a low degree of metal translocation into the aboveground section-translocation rates between roots and stems ranged from 0.02 to 0.16 for As and from 0.08 to 0.13 for $\mathrm{Pb}$. The high metal concentration in roots and apparent low translocation to the aboveground tissues indicates that the plant is capable of rather well-balanced uptake and translocation under heavy contamination conditions [34]. This may suggest a metal exclusion strategy from stems and reproductive tissue by retaining the metal in the roots [35], thus avoiding its toxicity. Resistance of $R$. ulmifolius to the metals can be achieved by an avoidance mechanism such as the precipitation and association with cell walls or detoxification in vacuoles [36,37]. Although each plant species might have a unique mechanism against heavy metals, other published data also indicates higher accumulation of As $[38,39], \mathrm{Pb}[29]$ and $\mathrm{Ni}[40]$ in the roots of plants growing in metal contaminated soils than in its aboveground tissues. $R$. ulmifolius also has shown the same type of accumulation behaviour for $\mathrm{Zn}$; plants accumulated up to 563, 110 and $91 \mathrm{mg} \mathrm{Zn} \mathrm{kg}^{-1}$ in the roots, stems and leaves, respectively, for a level of $\mathrm{Zn}$ in the soil of up $957 \mathrm{mg} \mathrm{kg}^{-1}$ [13]. This pattern of accumulation for all the studied metals truncates the biogeochemical cycles of the metals and limits potential food chain transfer to a restricted range of root consumer and decomposer organisms [37] of R. ulmifolius.

Additionally, the highest BCF values registered in this study were observed for the roots, and only in some of these cases were they higher than 1 . In fact, the BCF values for the aboveground tissues were lower than those registered for other non-hyperaccumulating species, namely for $\mathrm{Pb}$ in Gentiana penneliana [7] or for As in Pteris multifida [41], with values of BCF higher than 10. Nevertheless $R$. ulmifolius has shown increased accumulation abilities, considering the roots' BCFs, when compared to other species. For accumulation of $\mathrm{Pb}$ in Cyperus esculentus, Phyla nodiflora or even in another blackberry, Rubus fructicosus [7], reported BCF levels were lower than 1. The BCF has been used to evaluate the availability of heavy metals in contaminated soils [7,42]. Plants exhibiting BCF values lower than 1 in the aboveground tissues are referred to be unsuitable for phytoextraction [43], whereas high BCF values for the roots indicates potential for phytostabilisation, the latter being found in this study for R. ulmifolius. R. ulmifolius established successfully on this metal polluted soil, with metals being retained in the belowground sections. Additionally, this species presents significant biomass production in the field step, is well disseminated throughout the region and easy to propagate, characteristics that are desirable for a plant to be used in phytostabilisation approaches.

\section{Conclusions}

R. ulmifolius colonises a multi-metal contaminated site. The plants found in the area did not show visual toxicity signals, indicating tolerance to $\mathrm{As}, \mathrm{Pb}$ and $\mathrm{Ni}$, which were mainly accumulated in R. ulmifolius roots. Significant correlations were generally found between the total levels of metals in the soils and the accumulation in the roots, thereby exhibiting low metal translocation to its aboveground sections. This pattern of accumulation seems to indicate an exclusion strategy by this plant species. The use of $R$. ulmifolius for phytoremediation purposes should be effective when using the plant to reduce the effects of the contamination by the establishment of a green cover that immobilizes the metals, avoiding further distribution of the contamination via erosion or leaching, and, due to its low translocation capacities, decreasing the risks of passing $\mathrm{Pb}$, As and $\mathrm{Ni}$ into the food chain.

\section{Acknowledgements}

The authors wish to thank Câmara Municipal de Estarreja for the provision of access to the site. Ana Marques had the support of a Fundação para a Ciência e a Tecnologia grant SFRH/BPD/34585/2007. The work was funded by Project MICOMETA-POCI/AMB/60131/2004 (Fundação para a Ciência e Tecnologia). 


\section{References}

[1] Z.G. Shen, H.M. Chen, Bioremediation of heavy metal polluted soils, Rural EcoEnviron. 16 (2000) 39-44.

[2] X.Z. Hao, D.M. Zhou, Y.B. Si, Revegetation of copper mine tailings with ryegrass and willow, Pedosphere 14 (2004) 283-288.

[3] M. Del Rio, R. Font, C. Almela, D. Velez, R. Montoro, A.H. Bailóm, Heavy metals and arsenic uptake by wild vegetation in the Guadiamar river área after the toxic spill of the Aznalcóllar mine, J. Biotechnol. 98 (2002) 125-137.

[4] A.J.M. Baker, Accumulators and excluders: strategies in the response of plants to heavy metals, J. Plant Nutr. 3 (1981) 643-654.

[5] D.E. Salt, M. Blaylock, P.B.A.N. Kumar, V. Dushenkov, B.D. Ensley, I. Chet, I. Raskin, Phytoremediation: a novel strategy for the removal of toxic metals from the environment using plants, Biotechnology 13 (1995) 468-474.

[6] J. Pitchel, K. Kuroiwa, H.T. Sawyer, Distribution of $\mathrm{Pb}, \mathrm{Cd}$, and $\mathrm{Ba}$ in soils and plants of two contaminated sites, Environ. Pollut. 110 (2000) 171-178.

[7] J. Yoon, X. Cao, Q. Zhou, L.Q. Ma, Accumulation of $\mathrm{Pb}, \mathrm{Cu}$ and $\mathrm{Zn}$ in native plants growing on a contaminated Florida site, Sci. Total Environ. 368 (2006) 456-464.

[8] E. Pilon-Smits, Phytoremediation, Annu. Rev. Plant. Biol. 56 (2005) 15-39.

[9] J. Vangronsveld, F. Van Assche, H. Clijsters, Reclamation of a bare industrial area contaminated by non-ferrous metals: in situ metal immobilization and re-vegetation, Environ. Pollut. 87 (1995) 51-59.

[10] M.W. Wong, Ecological restoration of mine degraded soils, with emphasis on metal contaminated soils, Chemosphere 50 (2003) 775-780.

[11] P.B.A.N. Kumar, V. Dushenkov, H. Motto, I. Raskin, Phytoextraction: the use of plants to remove heavy metals from soils, Environ. Sci. Technol. 29 (1995) 263-290.

[12] M.J. Blaylock, J.W. Huang, Phytoextraction of metals, in: I. Raskin, B. Ensley (Eds.), Phytoremediation of Toxic Metals - Using Plants to Clean Up the Environment, Wiley-Interscience, New York, 2000, pp. 53-56.

[13] A.P.G.C. Marques, A.O.S.S. Rangel,P.M.L. Castro, Zn accumulation in plant species indigenous to a Portuguese polluted site: relation with soil contamination, J. Environ. Qual. 36 (2007) 646-653.

[14] W.S. Atkins, Estratégia de Redução dos Impactes Ambientais Associados aos Resíduos Industriais Depositados no CQE: Estudo de Impacte Ambiental (Environmental Impact Study), IPAMB No. 595, Lisbon, 1999.

[15] R.S. Oliveira, J.C. Dodd, P.M.L. Castro, The mycorrhizal status of Phragmites australis in several polluted soils and sediments of an industrialised region of Northern Portugal, Mycorrhiza 10 (2001) 241-247.

[16] V.J.G. Houba, J.J. van der Lee, I. Novozamsky, Soil Analysis Procedures, Department of Soil Science and Plant Nutrition, Wageningen Agricultural University, Syllabus, Wageningen, 1995.

[17] G.W. Thomas, Exchangeable cations, in: A.L. Page, R.H. Miller, D.R. Keeney (Eds.), Methods of Soil Analysis, Part 2, American Society of Agronomy and Soil Science Inc., Madison, 1982, pp. 159-165.

[18] I. Wallinga, W. Vark, V.J.G. Houba, J.J. Lee, Plant Analysis Procedures, Department of Soil Science and Plant Nutrition, Wageningen Agricultural University, Syllabus, Wageningen, 1989.

[19] A. Kabata-Pendias, H. Pendias, Trace Elements in Soils and Plants, CRC Press, Boca Raton, FL, 1984.

[20] B.J. Alloway, Heavy Metals in Soil, Blackie Academic and Professional, London, 1995

[21] H.J.M. Bowen, Environmental Chemistry of the Elements, Academic Press, London, 1979.

[22] E. Álvarez, M.L. Fernández Marcos, C. Vaamonde, M.J. Fernández-Sanjurjo, Heavy metals in the dump of an abandoned mine in Galicia (NW Spain) and in the spontaneously occurring vegetation, Sci. Total. Environ. 313(2003) 185-197.

[23] M. Greger, Metal availability and bioconcentration in plants, in: M.N.V. Prasad, J. Hagemeyer (Eds.), Heavy Metal Stress in Plants - From Molecules to Ecosystems, Springer Press, Berlin, 1999, pp. 1-27.
[24] B.E.M. Keller, K. Lajtha, S. Cristofor, Trace metal concentrations in the sediments and plants of the Danube Delta, Romania, Wetlands 18 (1998) 42-50.

[25] A.J. Cardwell, D.W. Hawker, M. Greenway, Metal accumulation in aquatic macrophytes from southeast Queensland, Australia, Chemosphere 48 (2002) 653-663.

[26] D.J. Wright, M.L. Otte, Wetland plant effects on the biogeochemistry of metals beyond the rhizosphere, Biol. Environ.: Proc. Roy. Irish Academy (1999) 3-10.

[27] C.G. van der Merwe, H.J. Schoonbee, J. Pretorius, Observations on concentrations of heavy metals zinc, manganese, nickel and iron in the water, in the sediments and in two aquatic macrophytes, Typha capensis (Rohrb.) N.E. Br. and Arundo donax L., of a stream affected by goldmine and industrial effluents, Water SA 16 (1990) 119-124.

[28] H. Deng, Z.H. Ye, M.H. Wong, Accumulation of lead, zinc, copper and cadmium by 12 wetland plant species thriving in metal contaminated sites in China, Environ. Pollut. 132 (2004) 29-40.

[29] E.J. Fitzgerald, J.M. Caffrey, S.T. Nesaratnam, P. McLoughlin, Copper and lead concentrations in salt marsh plants on the Suir Estuary, Ireland, Environ. Pollut. 123 (2003) 67-74.

[30] E. Stoltz, M. Greger, Accumulation properties of $\mathrm{As}, \mathrm{Cd}, \mathrm{Cu}, \mathrm{Pb}$ and $\mathrm{Zn}$ by four wetland plant species growing on submerged mine tailings, Environ. Exp. Bot. 47 (2002) 271-280.

[31] R.D. Reeves, A.J.M. Baker, Phytoremediation of toxic metals, in: I. Raskin, B.D. Ensley (Eds.), Using Plants to Clean Up the Environment, John Wiley and Sons Inc., New York, 2000, 193 pp.

[32] L.Q. Ma, K.M. Komart, C. Tu, W. Zhang, Y. Cai, E.D. Kennelley, A fern that hyperaccumulates arsenic, Nature 409 (2001) 579.

[33] R.S. Lavado, C.A. Porcelli, R. Alvarez, Nutrient and heavy metal concentration and distribution in corn, soybean and wheat as affected by different tillage systems in the Argentine Pampas, Soil Till. Res. 62 (2001) 55-60.

[34] N. Haque, J.R. Peralta-Videa, G.L. Jones, T.E. Gill, J.L. Gardea-Torresdey, Screening the phytoremediation potential of desert broom (Baccharis sarothroides Gray) growing on mine tailings in Arizona, USA, Environ. Pollut. 153 (2008) 362-368.

[35] A.J.M. Baker, R.R. Brooks, Terrestrial higher plants which hyperaccumulate metallic elements - a review of their distribution, ecology and phytochemistry, Biorecovery 1 (1989) 81-126.

[36] D.E. Koeppe, The uptake, distribution and effect of cadmium and lead in plants, Sci. Total Environ. 7 (1977) 197-206.

[37] M. Wierzbicka, How lead loses its toxicity to plants, Acta Soc. Bot. Pol. 1 (1995) 81-90.

[38] P. Madejón, J.M. Murillo, T. Marañon, F. Cabrera, M.A. Soriano, Trace element and nutrient accumulation in sunflower plants two years after the Aznacóllar mine spill, Sci. Total Environ. 307 (2003) 239-257.

[39] P. Madejón, J.M. Murillo, T. Marañon, N.W. Lepp, Factors affecting accumulation of thallium and other trace elements in two wild Brassicaceae spontaneously growing on soils contaminated by tailings dam waste, Chemosphere 67 (2007) 20-28.

[40] B.B.M. Nkoane, G.M. Sawula, G. Wibetoe, W. Lund, Identification of Cu and Ni indicator plants from mineralized locations in Botswana, J. Geochem. Explor. 86 (2005) 130-142.

[41] H.B. Wang, M.H. Wong, C.Y. Lan, A.J.M. Baker, Y.R. Qin, W.S. Shu, G.Z. Chen, Z.H. Ye, Uptake and accumulation of arsenic by 11 Pteris taxa from southern China, Environ. Pollut. 145 (2007) 225-233.

[42] S. Li, R. Liu, M. Wang, X. Wang, H. Shan, H. Wang, Phytoavailability of cadmium to cherry-red radish in soils applied composted chicken or pig manure, Geoderma 136 (2006) 260-271.

[43] W.J. Fitz, W.W. Wenzel, Arsenic transformation in the soil-rhizosphereplant system, fundamentals and potential application of phytoremediation, J. Biotechnol. 99 (2002) 259-278. 